Karadeniz Uluslararası Bilimsel Dergi

Volume: 42, Summer-2019, p. 83-90

ISSN: 1308-6200 DOI Number: 10.17498/kdeniz.549741

Research Article

Received: April 5, $2019 \quad$ Accepted: May 16, 2019

This article was checked by iThenticate

\title{
MENTALIY AND CULTURE OBSERVED DURING TRADITIONAL HOLIDAYS \\ (According To Ethnographic Materials On Adjara)
}

\author{
GELENEKSEL BAYRAMLARDA MUHAFAZA EDILEN MENTALITE VE \\ KÜLTÜR \\ (Acara Etnografik Malzemelerine Göre)
}

\author{
МЕНТАЛЬНОСТЬ И КУЛЬТУРА, СОХРАНЁННАЯ В \\ ТРАДИЦИОННЫХ ПРАЗДНИКАХ \\ (По этнографическим материалам Аджарии)
}

Davit SHAVIANIDZE*

\begin{abstract}
The problems with political and socio-religious life have arisen in Adjara, the historical community of Georgia, since the late Middle Ages. The internal development of culture has further deteriorated during the rule of Russians and Communist atheism, when the ideological machine became active, claiming that allegedly „the Adjarian is not Georgian“. This situation could not replace those socio-psychological factors, which ensured the development in accordance with national-ethnic sign. This is also confirmed by discovered ethnographic material on Georgian traditional holidays full of numerous rituals („Kvirikoba“, „Lazaria“, „New Year“, „Shuamtoba“, „Chkvanaroba“, „Kvishinaroba“, „Mareteloba“, „Chalaoba“) (using the comparative method, we apply to the realities reflecting the regularities of the self-consciousness function and ethnic feelings in everyday life and social relations of returnees settled in Ianeti).

The results of a complex and ethnohistorical study of new and the latest ethnographic material on the villages of Didachara, Skhalta, Khikhani and Mareti Valley are as follows: 1. Despite the fact that the imposed circumstances brought from another religion established the ethno-national lifestyle in accordance with the developments, the benchmark of national consciousness is not close to the dangerous points in Adjara. Sense of national identity among
\end{abstract}

\footnotetext{
* . ORCID 0000-0002-0568-1226, Assoc. Prof. Dr. Akaki Tsereteli State University/GEORGIA, (okribelisshvili@gmail.com )
} 
the deportees after settling in Ianeti was low (they used to say that they are of Meskhetian nationality or Georgian Muslims); 2. From the outset, the Georgian mentality has come to realize that freedom of religion is not only the rights, freedom or declarations, but also the need for preserving the own traditional religious knowledge, fitting it with the imposed belief and responsibilities. Thus, the goal of foreigners to change the mentality made the Georgians even strengthened the will of Georgians to maintain the social and spiritual balance (,come to Gamonatlevi, Gonio, Skhalta“, ,,always remember that Oshki, Tbeti and Khakhuli are our places“); 3. During the Communist regime, they occasionally changed the names of these holidays, and they were celebrated on non-working days established by the Government. They were aimed at maintaining faith and Georgian traditions and customs; 4 . The need for holidays is explained by the principles of „awaiting“ and „cause-and-effectiveness“. The approach is as follows: „If you want to have a healthy and prosperous life, you have to be in faith and devote your several days to the service of God“" your several days not regret God“; 5. Religious and folk festivities, along with the strengthening the unity, have been the guarantee of the preservation of a moral and ethical lifestyle that we inherited from our ancestors.

The study confirms the full preservation of Georgian mentality in the Mareti Valley.

Keywords: Georgia, Achara, Ethnography, Mareti, Religion.

\section{ÖZ}

Gürcistan'ın tarihi bölgesi Acara'da Orta Çağlardan itibaren siyasi, sosyal ve dini sorunlar ortaya çıkmıştır. Komünizm ve ateizm döneminde kültürel gelişmeler daha da zorlaştı. "Acaralı Gürcü değil" gibi ideolojik baskılar aktif hale getirildi. Tarih boyunca oluşan sosyal ve psikolojik durum ulusal ve etnik açıdan sağlanan gelişmelerin yerini tutamadı. Ritüellerle dolu geleneksel Gürcü şenlikler ("Kvirikoba”, "Lazaria”, "Axali Tseli”, "Şuamtoba", Çkvanaroba", Kvişnaroba"i Mareteloba", "Çalaoba") üzerine yapılan araştırmalar sonucunda elde edinilen bilgiler yukarıda bahsedilen tespitleri onaylamaktadır. (Araştırmada karşılaştırmalı metotlar uygulayarak Sürgünden geri dönen ve İaneti'de oturan halkın günlük hayatı ile sosyal ilişkilerinde öz bilinç ileetnik tutumların gerçekliği yukarıda bahsi geçen tespitlerce doğrulanmaktadır).Didacara, Skhalta, Khihani köyleri ile Mareti Vadisi'nde yapılan araştırmalar sonucunda elde edilen yeni etnografik malzemelere göre şu tespitler yapılabilir: 1. Farklı bir din tarafından oluşan durum dolayısıyla etnik ve milli hayattaki gelişmeler duruma uygun olmasına rağmen, Acara'da ulusal öz-bilinç ölçütü kritik seviyede değildir. İaneti'ye yerleşen ve sürgünden geri dönen kişiler arasında ilk aşamada ulusal öz-bilinç seviyesi düşüktür (Kendilerini Meskhi veya Müslüman Gürcü olarak tanımlamaktaydılar). 2. Gürcü zihniyeti baştan beri din özgürlüğünün yalnız hak, özgürlük veya tanınmalar şeklinde olmayacağını kendi geleneksel din kurallarının uygulanan yeni inanç ve yükümlülüklerle uydurulacağını anlamıştı. Böylelikle, yabancılar tarafından amaçlanan zihniyet değiştirme planı Gürcülerde sosyal ve manevi dengelerin korunması için yönlendirici bir etkiye sahipti (Gel Gamonatlevi'ye, Gonio’ya, Skhalta'ya". "Unutmayasın Oşki, Tbeti, Khakhuli bizimdir”). 3. Bazen şekli değiştirilen, ancak aynı anlamı taşıyan ve nesilden nesle taşınan şenliklerin isimleri Komünist rejim döneminde halk tarafindan bilerek değiştirilirdi ve hükümetin belirlendiği tatil veya bayram günlerine denk getirilirdi. Bütün bunlar "İnancın zayıflamaması, Gürcü hareket ve görüşlerinin korunması için yapılırdı".4. Şenliklerin gerekliliği "bekleme" ve "sebep ve sonuç" prensiplerine göre açıklanabilir. Yerlilerin yaklaşımlarına göre,sağlıklı kalmak ve uzun bir yaşam için bir kaç gün Tanrı'na hizmet etmek ve dindar olmak gerekir". Geleneklerle oluşan "sürdürülebilir normlar", 
ritüellerle belirlenen yasakların "gerekli görüldüğünde bozulması" gibi sosyal-kültürel durumdan kaynaklanırd1.5. Atalar tarafından birliğin pekiştirilmesi için miras olarak bırakılan dini bayramlar ve şenlikler ahlaki ve manevi yaşam tarzını sürdürmek için bir garanti oldu.

Araştırmalara göre Mareti vadisinde Gürcü zihniyetinin tamamen muhafaza edildiği tespit edilmiştir.

Anahtar Kelimeler: Gürcistan, Acara, Etnografya, Mareti, Din.

\section{АННОТАЦИЯ}

В исторической общине Грузии - Аджарии с периода средневековья настали политические и социально-религиозные проблемы бытья. Внутреннее развитие культуры ещё больше затруднилось со времён Российского правления и период коммунистического атеизма. Активно работала идеологическая машина, что „аджарцы не грузины“. Исторически сложившая ситуация не смогла вытеснить те социально-психологические факторы, которые обеспечили соответствующие национально-этническим признаки развития культуры. Собранные этнографические материалы о богатых ритуалах грузинских традиционных праздников („квирикоба“, „лазариа“, „новый год“, „шуамтоба“, „чкванароба“, „квишинароба“, „маретелоба“, „чалаоба“) подтверждают изложенные выводы в нижеследующем исследовании (в исследовании методом сравнения изучалось битье и социальные взаимоотношения репатриантов, живущих в с. Ианети. Закономерности функции самосознания отражают этническое настроение и реальность).

Выводы. комплексно изученных этно-исторических исследований, сделанные на основе новых и новейших материалов в селениях Дидаджара, Схалти, Хихани и Марети, таковы: 1. Несмотря на то, что внедренные чужие религиозные обстоятельства сформировали соответствующее сознание этно-национальном укладе, национальное самосознание в Аджарии не стоит у опасного предела. В момент переселения депортированных в с. Ианети, национальное самосознание было невысоким (о собственной национальности говорили, что они месхи, или грузинские мусульмане); 2. Грузинская ментальность тотчас же осознала, что религиозная свобода является не только правом, свободой или признанием, но и соотношением собственного традиционно-религиозного знания с навязанной религией и обязанностями. Таким образом, цель чужих, изменить ментальность, всё больше укрепляла социальное и духовное равновесие Грузин („Приходи в Гамонатлеви, Гонио, Схалта“; „Всегда помним Ошки, Тбети, Хахули наши“). 3. Иногда формоизмененые, но сохраненные по суть праздники, переданные через поколения, при коммунистическом режиме со стороны жителей проводились под другим именем в отведенные правительством выходные дни. Цель, такого мероприятия была сохранение веры и грузинского видения. 4. Необходимость праздников объясняются подходами „ожидания“ и «причинно-следственных» принципов. Подход такой: „для здорового, обильного бытия ты должен быть в вере, выделить несколько дней для богослужения“. Нарушение традиционных „устойчивых норм“, ритуальных запретов были вызваны социально-культурным положением среды. 5. Религиозные и народные праздники, наряду с укреплением единства, были гарантами сохранения оставленных предками нравственноморального уклада жизни.

Исследованием подтверждается полное сохранение грузинского менталитета в ущелье Марети.

Ключевые слова: Грузия, Аджара, этнография, Марети, религия. 
The choice of the theme for analyzing socio-cultural every-day problems of Adjara, as part of political Zemo Kartli region, had been guided by a painful political and religious past of this historical and ethnographic unit of Georgia. „When you were singing near the kvevry, I was shedding tears here“. „They were fighting against you, but you stood anyway, you could not say what you wanted to, could you tell me like him, would you be able to hold out for three hundred years? They were trying to take your language away from you... they have broken the Christ's cross, destroyed my grandfather's vineyard...“ “. The grave situation that has arisen in Adjara since the late Middle Ages, the internal development of Kartvelian culture has further deteriorated during the rule of Russians and Communist atheism, when the ideological machine became active, claiming that allegedly „the Adjarian is not Georgian“. „You didn’t treat me like brother, fighting against me, I am ashamed of you“; „You went back to your brother, What does that leave us, You repressed my Georgian soul, Are you not ashamed?" This is also confirmed by discovered ethnographic material on Georgian traditional holidays full of numerous rituals („Kvirikoba“, „Lazaria“, „New Year“, „Shuamtoba“, „Chkvanaroba“, „Kvishinaroba“, „Mareteloba“, „Chalaoba“) (using the comparative method, we apply to the realities reflecting the regularities of the selfconsciousness function and ethnic feelings in everyday life and social relations of returnees settled in Ianeti).

The aim of the work is to provide the future with ethnographic knowledge reflecting the historical past and present and compare it with modernity; to identify those sociopsychological circumstances, which ensured development a culture infused with national identity in accordance with ethnic characteristics.

Thesis: National identity, language, culture, mentality and other ethnic characteristics have been preserved in the historical community of Georgia - Adjara. Neither in the Middle Ages, nor in during the nor during the Russian Communist rule, there was not faltered the sense of cohesion with the nation, „often invisibly“, but still a sense of service-survival of it. Restriction on the exrcise of religious rights, the desire to change mentality, coercion to accept something unfamiliar and foreign made ${ }^{2}$ Georgian living in Adjara ready for maintaining social and cultural balance: „He was taking candle away of my hand, Breaking my church, I was singing Georgian hymns, But he wasn’t listening to me at all“; Selim Beg’s testament, Was positively soul-enriching, From Nicosia to Derbent, There is our Georgia“ (narrator, M. Makaradze. 2019: Oladauri).

\section{The content and characteristics of popular religious festivities.}

Religious holidays. The „Lazaroba“ bearing the name of Lazarus falled only on the Feast of Saint Ilya envisaged only in the Christian calendar, although rituals against droughts and fllods „were practicized all times during the threat to the harvest“. The required prayer accompanying rituals of „protecting from drought“: „Lazarus came to the door, He flashes his eyes, God, give us rain and water, Keep the sun and the moon for us”, during heavy rains, were said as follows: „God, give us the sun and the moon, Keep rain and water for us“. From the proven ethnographic material, we would highlight two significant circumstances proving the commitment to preservation of Georgian mentality, as follows: 1 . During the long periods of different religions and later in the period of atheism, through the Georgian pagan belief,

\footnotetext{
${ }^{1}$ The examples of folk poetry used in this work are translated by maintaining the accuracy of their content.

2 ,The Muslim religion has opposed the Christian religion, but the period of the Russian Communist rule was the epoch of complete disbelief“ (narrator. T. Eristavi-Sultanovi: Ianeti)
} 
the consciousness of the Adjarians preserved knowledge about Ilya, master of rains, hails and claps of thunder; 2. Clothing a cross-shaped stick with a woman's garment during the Ilyaoba/Lazaroba; Ashura is a traditional holiday. It is celebrated by both Christian and a Muslim in Adjara. The Feast is a bearer of the specifics of modified beliefs and imaginations of Georgians, who have been compelled to convert to Islam since the XVI century ${ }^{3}$; the residents of the Adjara community did not also forget the holidays associated with economic activities - „Kvirikoba“, and they celebrate it in the month of Churuba, that is, in the first week of July.

New and recent Adjarian ethnographic materials on religious holidays completely confirm the views of scientists on the role of rituals that accompany traditions and customs in ensuring harmony between mankind and nature relations on the role of rites associated with traditions and customs (Topchishvili, Khutsishvili, Gujejiani, 2010: 443, 447).

The life of each nation reflects traditions and experience economic activities according to natural-geographical environment, as well as the reality ensuring the strength of the community through achieving more or less economic stability. Traditional popular festivities of the Mareti Valley also point towards respect for the traditional rules of Kartvelian life is accordance with socioeconomic and cultural events unfolding in the country. Each of them was considered to be „the act of giving thanks to the Lord“. The prayer of first visitor to family at New Year (ethnographic material: „May you have sweetness and love. Let me good family. May you family get rid of evil. May you live in wealth and prosperity!“) and traditional customs (ethnographic material: „On New Year’s Day, you should have „gozinaki“ (chopped nuts boiled in honey), new broom and tablecloth. Boiled maize is a necessary attribute symbolizing the growth...") confirm the use of a sad „compulsory“ knowledge acquired from foreigners for the needs of national consciousness; with a view to increasing agricultural production and the number of animals for both food and movement purposes, the people of mountain areas of Georgia went to pasture in summer seasons. They used to grow crops that local environmental conditions allowed. They were mowing hay for livestock feeding in winter, and returned to their home in early autumn. In Adjara, there was also a custom to the so-called „iailas“ (Turkish name of mountain pasture, which was used in Adjara, but today nobody says ,iailas“, and everyone calls them summer pastures). The Highlanders from the Chikhrukha Valley celebrated together "Shuamtoba“, „Kvishnaraoba“, and “Chalaoba”" The characteristics that: „assembly“ and praying, special repast, entertainment only for two or three days. „You are in the mountains to generate wealth, and if all your time there you spent only on eating and drinking, God won't help you and you will not be able to accumulate wealth“. „Kesatoba“ has the same content - the first Saturday in April. On that day, nobody is allowed to work ${ }^{5}$.

The role of the regulator of the contradictory situation between two parts of society characteristic of traditional, ethnic culture, which was emerged on the basis of political and

\footnotetext{
3 „When cooking the dish „Ashura“, you should pour coins into it. The cooked dish „Ashura“ must be given to the neighbors. If the neighbor had a coin, that's a good sign“ (Shavianidze, Kamushadze, 2015: 43).

4 „Kvishinaroba“ was celebrated before „Shuamtoba“ (the names of holidays are from the place of origin. Chalaoba is the time of the beginning of „chala“ (the haymaking) in the valley, in July

5 „When people did not observe this rule, there were occurred such powerful mudflows, which swept away everything. One day, one head of the district sent the machines to work on this day. As soon as they finished to work, there was occurred such a powerful mudflow, which swept everything, including machines“
} 
religious influences, was also activated at the „appropriate time“ by „Maretoba“. This holiday was celebrated near the Gamonatlevi“ Church. influences has been activated at the „appropriate time“ celebration. The celebration was held with the Church of the Church. „The Christian religion has restablished the power again. The entire Mareti Valley has gathered, there are coming authorities and government representatives ${ }^{6}$. Gorbachev's rise (the General Secretary of the of the central Committee of the Communist Party in the 1980s - D. Shavianidze) was accompanied by religious freedom, but until then, this was not possible. During this holiday, there was announced the best representative of Mareti, notwithstanding religious affiliation. (narrators, G. Makaradze, M. Makaradze, A. Nakaidze, 2018: Oladauri).

Study has shown that in contact area between cultures - Adjara, the role of the preserver of ethnic identity was played by national circumstances and characteristics and the enduring norms and principles passed on to the generations and acting under the unwritten laws $^{7}$. In today's Adjara, for various reasons, many traditions go through a change and become lost. In this historical community of Georgia, starting from the Middle Ages and continuing to the 1980s, the policy imposed by foreigners was replaced by the era of a rapid exchange and sharing of the economic, cultural and other achievements. Ethnographic material: „There have also been cases when people changed the names of popular festivities. They celebrated them on non-working days established by the Government. There were adopted the restrictions. We refused to drink wine, but didn't stop praying, and God saw this, and we have survived. Georgian mentality and own faith didn't die“; on New Year's day, the people used to bring the Christmas treebranch to the entrance of the house and to the cattle barn $^{8}$. They used to scatter down the stones into the cattle hay-barn, and put the axe. As proof of the power, purity and inexhaustibility and constant current, the chef used to bring water in the morning. On New Year's Day, the people do not chop wood ${ }^{9}$. Today, all these traditions are rare and no longer have mass character. Almost no longer is proved the custom of bringing bread into the cattle stall and distributing it among all cows by the family housewife. In the past, on New Year's Day, there was a custom to bring only milk. On $14^{\text {th }}$ of January in the morning, the iron chain was brought into the cattle stall to signify that the animals would be together in the pasture. The sheep were brought into the house as „a sign of prosperity“. A custom of not doing the laundry on New Year's Day has become extinct. That is, that the people no longer believe that soapy water runs into the dead's eyes“; on „Lazaroba“, the

6 ,The holiday was established later in the Mareti Valley. The process has started since the 1980s. Solomon Putkaradze took the initiative of raising money for the church to be built. This was started as charitable activity. This initiative has gone beyond the Oladauri Municipality and has taken on a wider dimension, and one day, these people formed the Forum, I don't remember exactly what year. The Forum elected the coordinators, that is, the Society was established. The Society started to receive donations. Here, Karapeti was the only village, where the Muslim religion dominated. In other villages, there Christian religion prevails. They said that there are two Muslim centers in the world - Arabia and Karapeti. Money was raised from there as well. The church was built. Then, the State allocated some funds for roofing, making the fence and constructing the water supply system. It has been decided to organize such events, which attract more adherents from the city“ (narrators: V. Zoidze, B. Putkaradze. Makhalakizeebi. July, 2018).

7 „I am a pen of great Shota, Sulkhan-Saba's fable, the eagle of Luka from Chargali, tears of Mother of a Kartli, flown on a child, I am a Tato's Merani, tired in hand-to-hand combat. ... The bawls full of wine, may you empty them with love, and as proof of Georgian nature, let us grow vineyard again...“

8 „Once, people were living in the caves, or under the fir-trees. The fir-tree is putting up in tribute to this"

9 „If you chop wood, your cow or child will break their something“ 
people no longer chain to each other, the feastings have become rarely on this day; „Kvirokoba“ was non-working day. The old grandmothers used to go the vegetable gardens on in special cases on this day, and even then, they used to scatter down iron or nails ,to protect vegetables from maggots “ 10 . Today, only we, old people, remember about this custom“; no longer is being celebrated „Kvishinaroba“ and consequently the people no longer are preoccupied with horsemanship. No longer is the custom of kidnapping the aged highlander and his salvation on the "Shuamtoba" holiday. „Kesatoba“ and „Berikaoba“ are no longer celebrated.

The results of a complex and ethnohistorical study of new and the latest ethnographic material on the villages of Didachara, Skhalta, Khikhani and Mareti Valley are as follows: 1 . From the outset, the Georgian mentality has come to realize that freedom of religion is not only the rights, freedom or declarations, but also the need for preserving the own traditional religious knowledge, fitting it with the imposed belief and responsibilities; 2. Maintaining the folk beliefs and imaginations had its own log-frame ${ }^{11}$. The traditions and customs preserved in the depths of the centuries were fulfilled as ,a good thing for God“12 and were guarantee for a „health-rich“ state (,We believe in God, that is we've got belief. You will never do something nice for God without belief“" (narrator, Izno, 2000: Ianeti). 3. By celebrations, and an approach „do not regret God“, there shaped the principles of „awaiting“ and „cause-and-effectiveness“. A strong unity was preserved that demanded by the need for the principle of moral and ethical self-assertion bequeathed to us by our ancestors ${ }^{13}$.

Within the changed ethnological lifestyle of the Georgian communities, there was shaped the faith according to the occurring events, but the national self-consciousness benchmark has not come close to a dangerous point in Adjara: "Maize-bread rises in a clay pan, blessed by nanny, I hear my ancestors' voices - just plant a willow in the yard. They were fighting against us, but were not able to take the language, faith, homeland away from us, and they were unable to break our spirit, the strong Georgian spirit. Our ancestors have preserved our surname, our kind, roots, be worthy of their ancestry, my language, Christ's cross, ruler of my soul, even in a dream, I will pray for glory to the Adjarians (narrator, Makaradze. 2018: Oladauri).

\footnotetext{
${ }^{10}$ In our opinion this is explained by lack of faith

11 „The history of Georgia is our ancestors’ blood...“, „Service to the motherland is the duty of each Georgian...“ (narrator, Makaradze. 2018).

${ }^{12}$ Paul the Apostle: "imitate those who through faith and patience inherit what has been promised" (the Epistle to the Hebrews, 6:12).

${ }^{13}$ Sense of national identity among the deportees after settling in Ianeti was low (they used to say that they are of Meskhetian nationality or Georgian Muslims), but in Adjara, it was the other way around (,They were fighting against us, but were not able to take the language, faith, homeland away from us, and they were unable to break our spirit, the strong Georgian spirit..." [narrator, Makaradze. 2018: Oladauri]). Despite that, the strength of the national body resulted in fact that conqueror was not able to change completely a genotype of conquered people. Ethnographic material: „The older generation in the families of the Turk-Meskhetians is grateful for the fact that they live in the Christian world, although they still remain Muslims; before resettlement, our common religion, if only on an informal basis, was the Christian-Orthodox faith. We observed secretly the Christian rituals and customs and celebrated holidays. Of course, even today, among the holidays, we emphasize the Easter; we remember and know that Georgians celebrate holidays with wine, but now, wine is not allowed for us. Celebrations were accompanied with cultural entertainments for soul and body, which was not simple for our conqueror“. (narrator from Ianeti. See also Putkaradze, Kamushadze, Shavianidze. 2009)
} 


\section{REFERENCES}

Gvritishvili, D.,(1995), peodaluri sakartvelos sotsialuri urtiertobebis istoriidan, Tbilisi, 1995. Topchishvili, R., Khutsishvili, K., Gujejiani, R., (2010), teoriuli etnologia, Tbilisi, 2010. Lomsadze, Sh., (2000), meskhebi da meskheti, Tbilisi, 2000.

Sh. Nizharadze, (1961)ökartuli enis zemoacharuli dialeqtsi, Batum 1961.

Putkaradze, T., Kamushadze, G., Shavianidze, D.,(2009), ianeteli mesxebi (lingvo-kulturuli aspektebi). Akademikos sergi jikias dabadebis 110 tslistavisadmi midzgvnili sametsnierorespublikuri konperentsia, shromebi, Akhaltsikhe, 2009.

Gavtadze, G., Shavianidze, D., (2017), kartvelta saojakho-satemo kofia ekonomikuri safidzvlebi da shinaarsi (svanetis akhali etnograpiuli masalebis mikhedvit). meore saertashoriso konperencia, „tanamedrove ganvitarebis ekonomikuri, samartlebrivi da socialuri problemebi“. Konperenciis masalebi, 2017.

http://atsu.edu.ge/EJournal/BLSS.

Shavianidze, D., Kamushadze, G., (2015), Gürcü ve Türk Dillerinin Kültürel Dil Bilimi Etkileşimleri (Acara Şivesi'nin Kayıtlarına Göre). TÜRKOLOGIYYA. N1, BAKI 2015. 